\title{
Prospects of Oman as a Destination for Halal Tourism
}

\author{
Dr. Asad Rehman $a^{*}$ \\ ${ }^{a}$ Assistant professor, Department of Marketing and Entrepreneurship, College of Commerce and Business Administration, Dhofar \\ University, Salalah, Oman, asadrehman8@gmail.com \\ *Corresponding author.
}

Received: 27 September 2018, accepted: 14 October 2018, published: 2 March 2019

\begin{abstract}
Although a vast majority relates the concept of 'halal' or what is permissible in Islam to food only. However, halal industry covers many sectors such as food, fashion, transport, finance and even tourism. Halal tourism is not just about halal food, it is also about the overall experience, which is amenable with the Shariah (Islamic jurisprudence). Oman has a plethora of natural beauty and many places of interest for all types of tourists. It is one of the most secure and peaceful countries in the world. Having a well-developed Infrastructure, Oman is ready to take its tourism to new heights. The ever-hospitable Omanis are proud of their rich cultural and historical heritage. Thus, Oman appears to have all what it takes to become a prime destination for halal tourism. The objective of this study is to assess the prospects of Oman as a destination for halal tourism. Based on the interviews of experts like academicians, tourism professionals, officials and clerics, Oman's competitiveness as a destination for halal tourism was assessed by developing a Strengths, Weaknesses, Opportunities and Threats (SWOT) profile. The findings of the SWOT were compared with the data from the Global Muslim Travel Index (GMTI) from the year 2014 to 2018. Based on the analysis, Oman is found to have the right mix of environment and enabling services for halal tourism. However, it is found lacking in public transport, communication and customer outreach. Oman is also found to be losing its rank among the top 10 destinations for halal tourism to close competitors like Qatar, Bahrain, Morocco, etc. The concerned authorities need to make conscious efforts to resolve these issues as it becomes imperative for Oman to revamp its tourism strategy.
\end{abstract}

Keywords: Destination, Halal, Islam, SWOT, Tourism.

JEL codes: Z31, M31

\section{INTRODUCTION}

Halal tourism is the most recent subcategory of tourism which is primarily oriented towards Muslim families who wish to abide by the principles of Islam. Halal tourism is customized around the travel needs of Muslim tourists, who seek out a family friendly environment and destination. It is about halal food, halal finance, prayer breaks, etc. in addition to the routine tourism activities [8]. The tourism industry ensures that even the in-flight services also comply with the special needs of tourists availing halal tourism services or packages.

According to Crescent rating statistics, in 2014 Malaysia, Turkey and the UAE were among the top Muslim-friendly destinations for travelers. The expenditure of the halal tourism sector was more than \$145 billion in 2014 [5]. The global value of the halal travel industry is estimated to grow to $\$ 233$ billion by 2020 [6]. Based on the above estimates, halal tourism market appears to be very lucrative and promising for all the players in the field of tourism marketing.

\section{LITERATURE REVIEW}

\subsection{Concept of Halal Tourism}

https://doi.org/10.30585/icabml-cp.v2i1.213

(C) 2018 the Authors. Production and hosting by Avicenna FZ LLC. on behalf of Dubai Business School, University of Dubai - United Arab Emirates. This is an open access article under the CC BY-NC license. 
Various factors influence tourist behavior; religion is one of them, such as the choice of destinations and tourism product preferences [20]. Muslim life is directed by the Quranic commandments and the Hadith, containing the sayings and deeds of the Prophet Muhammad (Peace be upon him) [21]. Based on the Islamic outlook of God, man and nature, travel and tourism is fundamental to mankind [9]. Even during traveling, Muslims are expected to respect fundamental Islamic principles. Halal tourism seeks to assimilate religious motivations, with the Western type of tourism practices, which presently guide the modern tourism industry. Basically, it means that a tourist may enjoy his or her tour without having to compromise on the religious obligations.

Though, there exists some confusion between the terms 'halal tourism' and 'Islamic tourism'. However, using 'halal tourism' and 'Islamic tourism' as the same terms is not justifiable. The term halal is defined as "That which is permitted, with respect to which no restriction exists, and the doing of which the law-giver, Allah, has allowed" [1]. Therefore, halal term means 'permissible' according to Islamic law (Sharia). Whereas, the term 'Islamic' is precisely applied only to that which relates directly to Islam and its principles [7]. Islamic tourism is the one which is undertaken purely with the intention to fulfill some religious obligation such as Haj or Umrah.

The most important factors in favor of halal tourism came out as: Privacy for the family (73\%) followed by alcohol free experience $(62 \%)$ followed by halal food (34.6\%) followed by punctuality for prayers (33\%). Nowadays it is a common observation that most of the tourist destinations are overcrowded and one has to be really on a constant guard for the family [17] [18]. Just like the concern of vegetarians like Jains and Buddhists, the concern of Muslims is pretty much genuine about halal food. The concern for offering prayers on time comes at the third place is mainly because not all the Muslims are steadfast in their prayers.

It is notable that halal tourism may appear to be having Islamic overtones but it is equally applicable to the people of other religions who are more conscious about their privacy and food habits. Halal tourism is not limited to Muslim travelers only, since the concept is 'family-oriented', the market can expand to the non-Muslim population as well [17]. To sum up, Halal tourism is "any tourism object or action which is permissible according to Islamic teachings to use or engage by Muslims in tourism industry". Therefore, it includes services and products that are designed for Muslim travelers in Muslim and non-Muslim countries. Furthermore, the definition considers the purpose of travel is not necessarily religious.

\subsection{Needs of Muslim Tourists}

There is a recently growing awareness among the Muslims to select Halal options for their needs from the common of options currently offered [2] [14]. Therefore, some destinations such as Japan, the Philippines and Brazil are offering Muslim-friendly options to situations seen as problematic by Muslim travelers. Prayer rooms are allocated at major airports, and restaurants offer Halal food in Japan. Muslim-friendly guide is also published to provide information on Halal food and prayer places [19]. Some of the foremost requirements of Muslim travelers are mentioned below:

Halal hotels and halal food Halal hotels provide Muslim guests with services such as Qibla direction that should be faced for Muslim prayers, Halal food, alcohol-free beverages and prayer room with call for prayers [3]. Japan is one of the nonMuslim countries that take initiatives towards training the hospitality staff by launching Muslim-Friendly Project [15]. Travel guide in Kyoto city website is provided for Muslims in four languages: Arabic, English, Turkish and Malay. The website provides list with Muslim-friendly hotels [16]. Aerostar Hotel in Moscow is Muslim friendly as one of the hotel's kitchens is certified Halal [12]. The hotel also places the Holy Quran, a prayer rug and indicates the prayer direction for Muslim guests in about 20 of its rooms. Even the personal care products like shampoo and soap placed in the rooms are Halal certified. Separate prayer rooms are available for men and women [4].

Muslim-friendly airport is recently one of the best practices to delight Muslim travelers. The numbers of visitors from the Southeast Asian Muslim countries of Malaysia and Indonesia in recent year increased in Osaka [10]. Kansai airport allocates three prayer rooms segregated by gender for the use of travelers. There are water friendly toilets and washing space is provided to perform ablution for praying. Fifteen restaurants prepare Halal food promoted as 'pork-free and alcohol-free menus', and three restaurants are 'Halal certified'. Using availability of Muslim-friendly airport can be used to attract Muslim travelers.

Smartphone Application One of the recent innovative practices in Halal tourism industry is providing smart-phone application that makes the holiday more convenient. Thailand has launched Muslim-friendly application to help tourism industry in Thailand [11]. It helps visitors to find hotels and shopping avenues with prayer rooms and restaurants with 
Halal food. In addition to this, there are halal holiday packages, halal cruise, halal healthcare services, etc. which may augment the entire experience.

\section{METHODOLOGY}

The present study is primarily based on secondary data obtained from previous researches on the halal tourism. The researcher also conducted interviews of 30 respondents comprising academicians, students, hotel managers, clerics and officials from the ministry of tourism in Oman. Due care was taken to include the opinion of non-Muslim respondents as well. The purpose was to develop a SWOT (Strengths, Weaknesses, Opportunities and Threats) profile of Oman with special reference to halal tourism. The following research questions were discussed with the respondents:

\section{Q1: What are Oman's strengths as a potential destination for halal tourism? \\ Q2: What are Oman's weaknesses as a potential destination for halal tourism?}

Q3: What are the major threats to Oman as a potential destination for halal tourism?

Q4: What opportunities does halal tourism open up for Oman?

Additionally, data from Global Muslim Travel Index (years 2014-18) was also referred to, which has been duly summarized and analyzed.

\section{FINDINGS AND ANALYSIS}

\subsection{Halal Tourism in Oman}

As per the vision statement of ministry of tourism, Oman aims to become, by 2040, a top of the mind destination for vacations, discovery, and meetings, attracting eleven million international and local tourists annually. Undoubtedly, Oman has all the ingredients of a leading tourist destination. It has some of the most beautiful mosques, awe inspiring nature and wild life. Oman has some of the most beautiful beaches spanning over 3165 Kilometers coastline offering a variety of aquatic activities [22]. Deserts and Bedouin life in Oman are yet another tourist attraction. Oman has a lot to offer to the adventure seeking travelers in the form of rock climbing, hiking, desert safari, etc. It has a well preserved cultural heritage and has a lot of colors in the form of its music and dance, handicrafts, Omani food, etc. Although, there is no deliberate effort by the ministry to position Oman as a destination for halal tourism, still it has emerged as one of the top 10 destinations for halal tourism as evident in Table-1.

TABLE-1

The Top 10 OIC* Destinations of Global Muslim Travel Index (GMTI) from 2014 to 2018

\begin{tabular}{|c|c|c|c|c|c|}
\hline Rank & $\mathbf{2 0 1 4 * *}$ & $\mathbf{2 0 1 5}$ & $\mathbf{2 0 1 6}$ & $\mathbf{2 0 1 7}$ & $\mathbf{2 0 1 8}$ \\
\hline 1 & Malaysia & Malaysia & Malaysia & Malaysia & Malaysia \\
\hline 2 & UAE & Turkey & UAE & UAE & Indonesia \\
\hline 3 & Turkey & UAE & Turkey & Indonesia & UAE \\
\hline 4 & Indonesia & $\begin{array}{c}\text { Saudi } \\
\text { Arabia }\end{array}$ & $\begin{array}{c}\text { Indonesi } \\
\text { a }\end{array}$ & Turkey & Turkey \\
\hline 5 & $\begin{array}{c}\text { Saudi } \\
\text { Arabia }\end{array}$ & Qatar & $\begin{array}{c}\text { Qatar } \\
\text { Saudi }\end{array}$ & Saudi Arabia \\
\hline 6 & Morocco & Indonesia & $\begin{array}{c}\text { Saudi } \\
\text { Arabia }\end{array}$ & Qatar & Qatar \\
\hline
\end{tabular}




\begin{tabular}{|c|c|c|c|c|c|}
\hline 7 & Jordan & Oman & Oman & Morocco & Bahrain \\
\hline 8 & Qatar & Jordan & Morocco & Oman & Oman \\
\hline 9 & Tunisia & Morocco & Jordan & Bahrain & Morocco \\
\hline 10 & Egypt & Brunei & Bahrain & Iran & Kuwait \\
\hline \multicolumn{7}{|c|}{$*$ Organization of Islamic Cooperation } \\
$* *$ Crescent Halal Friendly Travel Ranking [13]
\end{tabular}

As apparent from Table-1, Oman has moved into the top 10 destinations among OIC nations for halal tourism purpose. From a ranking of below 10 in 2014, Oman went up to rank 7 in the years 2015 and 2016 and later went marginally down by one rank in the years 2017 and 2018 [13]. It becomes mandatory to look into some aspects which make Oman as one of the ideal destinations for halal tourism.

\subsection{SWOT Analysis of Oman for halal tourism}

Based on the interviews of the respondents, a SWOT Analysis of 'Oman as an ideal destination for halal tourism' is presented below. The following SWOT covers the dimensions which are of particular relevance to halal tourism only.

\section{Strengths}

$>$ Omani people are very hospitable and welcoming for tourists. They respect the privacy of other people. Omani society is based on the tenets of religious tolerance.

$>$ It is a Muslim country with strong roots in the culture and faith of Islam. Alcohol is served only in a few five-star hotels. Hotels in Oman do not serve alcohol till $2 \mathrm{pm}$ on any Friday and 24 hours prior to Haj day (Annual Pilgrimage for Muslims) and the three days of Eid are completely dry.

$>$ Omani law preserves Islamic values. For example, during the month of Ramadan eating in public place during the daytime is a punishable offence.

$>$ There is a lot of respect for women. Women cab drivers are available for the females travelling alone.

$>$ Availability of halal food, separate spaces for families and individuals in all restaurants, separate prayer space for males and females is abundantly available. There are separate timings for males and females in some swimming pools and aqua parks.

$>$ Availability of halal finance. For example, bank Meethaq offers interest free loans for travelling purpose.

$>$ By default, almost all resorts in Oman provide halal travel packages. There are many four star and fivestar hotels like the Coral Muscat, the Platinum, the Muscat Grand Millennium, etc. which are Shariah compliant.

$>$ Police in Oman is very efficient and helpful. It keeps an eye over the activities of the tourists in public places and tries to control any kind of mishap like some tourists breach the norms of decency in public places.

\section{Weaknesses}

$>$ There is a lack of general awareness among people about halal tourism in Oman.

$>$ Relevant and user-friendly information about halal tourism in Oman is not widely available. Surprisingly, it is missing on the website of the ministry of tourism, Oman. Only some superficial information is available on the websites like www.thebettervacation.com[23] and in the newspaper articles of the Times of Oman[24], the Oman Observer[25], etc.

$>$ Lack of effort in informing Western tourists of their responsibility to respect Islamic traditions and uphold norms of decency in Oman. This often leads to very embarrassing situations.

$>$ Lack of initiative by the concerned authorities in projecting Oman as a destination for halal tourism. Oman has a low digital presence and not many tourists around the world are aware of Oman as a tourist destination. 
$>$ There are no unique experiences in Oman which may be used as a crowd puller.

$>$ Omani culture is Islamic and conservative, which may not be very comfortable for some of the nonMuslim tourists. This is in favor of halal tourism however; it is a major put off for many tourists coming from liberal western countries.

$>$ Alcohol is served in some of the hotels.

$>$ No separate swimming space for men and women in five star rated hotels.

$>$ Sometimes the tourists are found indulging in indecent activities in public places like beaches, airports, shopping malls, etc.

\section{Opportunities}

$>$ There is an opportunity for branding and positioning Oman as a halal tourism destination.

$>$ Creating awareness about tourism in Oman.

$>$ Developing halal tourism products for families, newlywed couples (like halal honeymoon package), etc.

$>$ It is likely to broaden the horizon of tourism and will create new employment opportunities.

$>$ Courses on halal tourism may be introduced in the universities and colleges.

$>$ Special events may be created on halal tourism theme to attract more tourists.

$>$ Entertainment programs should be developed on the halal theme.

$>$ It should be the effort to create a universal appeal of such programs.

$>$ Places related to Islamic heritage should be identified and developed into tourist spots with all amenities.

\section{Threats}

$>$ Intense competition from close competitors like Morocco, Qatar, Saudi Arabia, Bahrain which are already among the top 10 OIC nations for halal tourism.

$>$ It may lead to the stereotyping of Oman as a fundamentalist country.

$>$ It may lead to a loss of non-Muslim travelers to Oman. Muslim travelers who are a little less steadfast in observing the teachings of Islam may also desist from coming to Oman.

$>$ High operational cost of halal tourism packages.

$>$ Reluctance of investors to invest in dry (alcohol free) hotels.

\subsection{Analysis based on Mastercard-Crescentrating Global Muslim Travel Index (GMTI)}

Crescent Rating has studied the halal tourism market and has benchmarked destinations with the annual MastercardCrescentrating Global Muslim Travel Index (GMTI) since 2011.The GMTI adopts the most recent set of measurements to better point out the level of Muslim-friendly travel of each destination. The ratings are based on the factors like ease of access, communication and outreach, environment and enabling services which are relevant to halal tourism [13].

Tables-2(a) and (b) capture the top 10 halal destinations worldwide from 2017 and 2018. Oman is present in the top 10 across all factors in 2017 but in the year 2018 it is among the top 10, only in case of enabling services. This is a serious issue which cannot be ignored if Oman aims to fulfill its vision 2040.

A brief factor wise analysis of the table-2(a) with special reference to Oman is presented below:

1) Ease of Access of destinations is dependent on the scores of air connectivity and visa free travel. Transport infrastructure is another metric added in 2018. Oman ranked sixth in the year 2017 and in 2018 it is not in the top 10 destinations. Oman has good air connectivity and relaxed visa requirements (refer to table 3). But it lacks in adequate public transport infrastructure. The only other mode of transport available is road transport mainly by cars and buses. This is not only expensive but also time consuming.

TABLE-2 (a)

The Top 10 Destination and Factors of Halal Tourism [13] 


\begin{tabular}{|l|l|l|l|l|}
\hline Rank & \multicolumn{2}{|l|}{ Ease of Access } & \multicolumn{2}{l|}{ Communication \& Outreach } \\
\hline & $\mathbf{2 0 1 7}$ & $\mathbf{2 0 1 8}$ & $\mathbf{2 0 1 7}$ & $\mathbf{2 0 1 8}$ \\
\hline 1 & Turkey & Turkey & Malaysia & Malaysia \\
\hline 2 & Malaysia & Malaysia & Indonesia & Indonesia \\
\hline 3 & UAE & Singapore & UAE & Singapore \\
\hline 4 & Qatar & UAE & Singapore & Thailand \\
\hline 5 & Singapore & Hong Kong & Bahrain & Japan \\
\hline 6 & Oman & Germany & Qatar & UAE \\
\hline 7 & Indonesia & Netherlands & Oman & New Zealand \\
\hline 8 & Morocco & France & Morocco & Brunei \\
\hline 9 & Saudi Arabia & UK & Saudi Arabia & Bahrain \\
\hline 10 & Bahrain & South Korea & Turkey & Australia \\
\hline
\end{tabular}

2) Communication \& Outreach refer to a destination with an excellent ease of communication level as well as a good awareness on Muslim travel needs and outreach towards Muslim travelers. Digital presence is added in 2018. Oman ranked seventh in the year 2017 and in 2018 it is not in the top 10 destinations. Oman is relatively well placed in terms of ease of communication. However, it is lagging behind others in digital presence and customer outreach (refer to table 3).

Table-2(b) with special reference to Oman is presented below:

TABLE-2 (b)

The Top 10 Destination and Factors of Halal Tourism [13]

\begin{tabular}{|l|l|l|l|l|}
\hline Rank & \multicolumn{2}{|l|}{ Environment } & \multicolumn{2}{l|}{ Enabling Services } \\
\hline & 2017 & 2018 & 2017 & 2018 \\
\hline 1 & Malaysia & Singapore & Malaysia & Malaysia \\
\hline 2 & Turkey & UAE & Saudi Arabia & Indonesia \\
\hline 3 & UAE & Turkey & UAE & Saudi Arabia \\
\hline 4 & Singapore & Malaysia & Qatar & UAE \\
\hline 5 & Morocco & Hong Kong & Indonesia & Egypt \\
\hline 6 & Bahrain & Saudi Arabia & Oman & Turkey \\
\hline 7 & Saudi Arabia & kazakhstan & Bahrain & Qatar \\
\hline 8 & Indonesia & Spain & Turkey & Oman \\
\hline 9 & Oman & Japan & Morocco & Bahrain \\
\hline 10 & Qatar & Bahrain & Singapore & Iran \\
\hline
\end{tabular}


3) Environment refers to the overall family-friendliness of the destination; number of Muslim visitor arrivals, safety and culture determines a good travel environment for Muslim travelers. Oman ranked ninth in the year 2017 and in 2018 it is not in the top 10 destinations. This is a surprising result and it may be attributed to a low score for visitor arrival (refer to table 3).

4) Enabling Services refer to the level of Muslim-friendly services that each destination offers is based on the destination's halal dining options, prayer spaces, airport facilities and accommodation options. Unique experiences metric is added in 2018. Oman ranked sixth in the year 2017 and in 2018 it has slipped down to the rank number eight. Oman needs to consolidate itself on this parameter at least because this is where Oman scores high over its competitors. With a below 50 score of 47 against accommodation options (refer to Table-3), Oman needs to offer more accommodation choice ranging from dormitories to luxury hotels at affordable rates to its tourists.

Table 3 clearly shows that Oman has safety and culture, airport facilities, ease of access to offer prayers, dining options, air connectivity, visa requirements and ease of communication as its major advantages in terms of being a halal tourism destination. However, it is found lacking in enabling climate, visitor arrival, digital presence, customer outreach, unique experiences, accommodation options and availability of public transport.

TABLE-3

GMTI of Oman from 2017 to 2018 [13]

\begin{tabular}{|c|c|c|c|}
\hline S. No. & Parameters & $\begin{array}{l}2017 \\
\text { Score }\end{array}$ & $\begin{array}{l}2018 \\
\text { Score }\end{array}$ \\
\hline 1 & Enabling climate & 41.2 & 56 \\
\hline 2 & Safety and culture & 94 & 94 \\
\hline 3 & Visitor arrival & 12.6 & 29 \\
\hline 4 & Dining options & 80 & 80 \\
\hline 5 & Ease of access to prayer space & 100 & 100 \\
\hline 6 & Airport facilities & 100 & 100 \\
\hline 7 & Unique experiences & $\ldots .$. & 10 \\
\hline 8 & Accommodation options & 47.7 & 47 \\
\hline 9 & Ease of communication & 66.5 & 64 \\
\hline 10 & Digital presence & $\ldots .$. & 24 \\
\hline 11 & Outreach & 31.3 & 31 \\
\hline 12 & Air connectivity & 78.4 & 75 \\
\hline 13 & Visa requirements & 63.9 & 69 \\
\hline 14 & Transport infrastructure & $\ldots .$. & 36 \\
\hline 15 & Composite score & 67.9 & 65.1 \\
\hline
\end{tabular}




\section{DISCUSSION AND CONCLUSION}

Despite sliding down marginally, Oman still has a GMTI rank 9 worldwide in 2018 [13]. However, it needs to look into certain aspects of its tourism management almost immediately.

First, it has to keep a watch over its close competitors like Bahrain, Morocco, Tunisia, Egypt, Iran and Kuwait. Oman is lacking a Unique Selling Proposition (USP) for its tourism. It needs to meaningfully differentiate its tourism from that of its rivals and come up with a strong brand positioning for itself. 'Beauty has an address' the punch line of Oman tourism is vague and lacks tangible benefits for the tourists.

Second, the concerned authorities along with other players in the field of tourism need to seriously and deliberately position Oman as a unique destination for halal tourism.

Based on the SWOT analysis and inputs from GMTI rankings and scores it is evident that Oman is nothing short of being an ideal destination for halal tourism. However, it has to make the most of on its strengths to capitalize upon the opportunities created by a surge in halal tourism worldwide.

Third, it needs to resolve the lack of digital presence and customer outreach by actively participating in the relevant forum like travel blogs, trade exhibitions, conferences, digital marketing, etc. Oman tourism needs to upgrade its website and needs to make it more interactive and user friendly. Some of the information on its website is in Arabic only which needs to be translated into English at least. Pages on halal tourism need to be added to the current website with suitable links to hotels, travel agents, restaurants, etc.

In fact, there is an imminent need to educate the masses about halal tourism and its advantages. Once people come to know that it is not akin to pilgrimage or Islamic tourism, it will have a universal appeal for all the tourists irrespective of their faith. Halal tourism is about family, privacy, good wholesome food \&drinks and clean idea of fun.

Fourth, lack of accommodation options and availability of public transport are two weak areas of Tourism in Oman. The concerned authorities need to take up these issues on a priority basis. There is a strong need to create some unique experiences and activities about halal tourism in Oman which are inimitable by others in the fray.

In addition to the above-mentioned steps, Oman needs to undertake suitable marketing and advertising programs targeting the families. The overall environment and culture of Oman is ideal for halal tourism. Oman only needs to revisit its tourism strategy and revise it to give a formal recognition to halal tourism.

\section{REFERENCES}

[1]Al-Qaradawi, Y. (2013). The lawful and the prohibited in Islam: Shoruuk InternationalAndriani, D., Khalikal, K.A., Aqmarina, L., Nurhayati, T., Permanasari, I.K., Binarwan, R., et al. (2015), Preliminary Report of Study of Shariah Tourism Development. Jakarta: Kemenpar applications. Current Issues in Comparative Education, 7(1), pp: 5-18.

[2]Battour M, Ismail MN. (2014), The role of destination attributes in Islamic tourism. SHS Web of Conferences. Vol. 12. p. 01077

[3]Battour M, Ismail MN, Battor M.(2010), Toward a halal tourism market. Tourism Analysis., Vol.15, pp:461-470

[4]Battour, M., \& Ismail, M.N., Halal tourism: Concepts, practises, challenges and future, Tourism Management Perspectives (2015), http://dx.doi.org/10.1016/i.tmp.2015.12.008

[5]Crescentrating. (2015). DOI: http://mtsi.crescentrating.com/.

[6]Dinarstandard.com. (2012), Global Muslim Lifestyle Tourism Market: Landscape \& Consumer Needs Study. Retrieved on 15.10.16from http://advisory.dinarstandard.com/travelstudy/

[7]Douglass, S. L., \& Shaikh, M. A. (2004). Defining Islamic education: Differentiation and applications. Current Issues in Comparative Education, 7(1), 5-18. 
[8]Hasan, Deeba (2016), Halal tourism becoming popular among tourists travelling from Oman, Times of Oman, July 11, 2016.

[9]Hasharina, N.; N. Hashim; J. Murphy, and N. Muhammad. (2006). Tourism and Islam, understanding and embracing the opportunity.

[10]KIX MFA. . (2015), Muslim Friendly Airport KIX. 20 Apr 2015. Available from: http://www.osakainfo.jp/en/news/muslim_friendly_airport_kix.html

[11]Lefevre AS. (2015), Thailand launches Muslim-friendly tourist app. 9 May $2015 . \quad$ Available from:http://www.reuters.com/article/2015/06/29/us-thailand-tourism-idUSKCNOP918F20150629

[12]Marika Sboros.(2014) Moscow Hotel Goes 'Halal' in Bid to Attract Global Muslim Visitors. Available from: http://www.biznews.com/travel/2014/10/27/moscow-hotelgoes-halal-bid-attract-muslim-visitors-around-world/

[13]Mastercard \& Crescentrating Global Muslim travel Index, for the years 2014, 2015, 2016, 2017 and 2018.

[14]Muhammad M. (1989), Toward Islamization of Disciplines. Herndon, VA: The International Institute of Islamic Thought.

[15]Muslim Friendly Project. (2015), Muslim Friendly Project. 3 May 2015. Available from: http://muslim-friendly-japan.com/tours/

[16]Muslim Friendly Kyoto. (2015), Muslim Friendly Kyoto. 5 May 2015. Available from: http://kyoto.travel/muslim/

[17]Rehman, A. and Jamila Jaboob (2017) "Exploring Consumer Attitude Towards Halal Tourism in Salalah: Implications for Tourism Marketing", Omani Journal of Applied Sciences, Vol. 6, pp: 102-109

[18]Sriprasert,P., Oraphan Chainin and Hamzah Abd Rahman (2014), "Understanding Behavior and Needs of Halal Tourism in Andaman Gulf of Thailand: A Case of Asian Muslim", Journal of Advanced Management Science,Vol.2, No.3,pp:216-219.

[19]The National (2014), Japan Woos Muslim Travellers Ahead of 2020 Olympic Games. 14 Aug 2014. Available from: http://www.thenational.ae/world/east-asia/japan-woos-muslimtravellers-ahead-of-2020-olympic-games

[20]Weidenfeld, A. and A. Ron, (2008). "Religious needs in the tourism industry," Anatolia: An International Journal of Tourism and Hospitality Research, vol. 19, no. 2, pp. 357-361,

[21]Zamni-Farahani, H. and J. C. Henderson (2010), "Islamic tourism and managing tourism development in Islamic societies: The cases of Iran and Saudi Arabia," International Journal of Tourism Research, vol. 12, pp. 79-89.

[22] https://omantourism.gov.om, accessed on 12.06 .2018

[23] https://thebettervacation.com/halal-holidays-in-oman-muslim-friendly-travel/, accessed on 12.06.2018

[24]http://timesofoman.com/article/99386, accessed on 12.06.2018

[25]http://2016.omanobserver.om/halal-tourism-getting-popular-in-oman/, accessed on 12.06.2018

Dr. Asad Rehman, having a teaching experience of more than 19 years, is presently serving as an Assistant Professor in the Department of Management and Marketing, CCBA, Dhofar University, Salalah. He has served as the Chair of the MBA program in CCBA, Dhofar University. His parent organization is Aligarh Muslim University in India where he is an Associate Professor in the Faculty of Management Studies \& Research.

Born in Meerut, India on 08.10.1973, he obtained his BA in the year 1994 in History hons, later he did MBA in 1996 in Marketing and Finance and finally he was awarded his PhD in consumer behavior in 2011. All his degrees are from Aligarh Muslim University, India.

His areas of interest are Marketing and communication. He has successfully supervised four doctoral theses in Business Administration. He is an avid researcher and has contributed papers in several reputed research journals. He has presented papers in several international conferences. Lately he has presented research papers on 'halal tourism' in Oman and has one publication in an Omani journal on this subject. 